\title{
MENINGKATKAN KEMAMPUAN PEMECAHAN MASALAH MATERI PECAHAN MELALUI PENDEKATAN PENDIDIKAN MATEMATIK REALISTIK (PTK DI KELAS IV SDN PADASUKA 2 PASIRWANGI GARUT )
}

\author{
Ani Siti Anisah \\ Program Studi PGMI Universitas Garut \\ Jl. Samarang No. 52A Garut \\ Email: sitianisah@uniga.ac.id \\ Ani Yanti Ginanjar \\ Program Studi PGSD Universitas Garut \\ Jl. Samarang No. 52A Garut \\ Email: aniyantiginanjar@uniga.ac.id \\ Dadan Hermawan \\ Program Studi PGMI Universitas Garut \\ Jl. Samarang No. 52A Garut \\ Emai: dadanhermawan446@gmail.com
}

\begin{abstract}
This research objective is to increase math problem solving competences on fraction through Real Mathematic Education (RME) for $4^{\text {th }}$ grade students. The type of this research is Penelitian Tindakan Kelas (PTK) Kolaboratif. The researchers work collaboratively with teachers as the executor on the learning activities. Subject of this research are $4^{\text {th }}$ grade students in SD Negeri Padasuka 2 Kecamatan Pasirwangi Kab. Garut. Data collecting in this research is using test with short answers which conducted in the end of each cycle and observation by the researchers. Students and teachers learning activity data is analyzed in descriptivequalitatively while the competence on problem solving data result is analyzed in descriptive-quantitatively with table and percentage visualization. The result of this research shows that Real Mathematic Education which done with RME steps that based on RME characteristics are using contextual problems, model-usage, students contribution, interactive activity, and topic relation can improve students ability to solve the problem. The average score before the activity was 62,78 with learning completeness $37.84 \%$, while on the first cycle is 63,76 with learning completeness 54,05 , in the second cycle is 71,57 with learning completeness $75.68 \%$, and lastly, the average score by the third cycle is 73,30 with learning completeness $86,49 \%$. Then it can be concluded that the application of Realistic Mathematics Education (PMR) can increase teacher activity and student activities so that it has an impact on increasing the ability of students to solve the problem of fraction addition and reduction of fractions of grade IV SD Padasuka 2 students.
\end{abstract}

\section{Keywords: \\ Mathematic learning results, Real mathematic education approach, fraction problem solving competences.}

\begin{abstract}
Abstrak
Penelitian ini bertujuan untuk meningkatkan kemampuan memecahkan masalah matematika pecahan melalui Pendidikan Matematika Realistik pada siswa kelas IV. Jenis penelitian ini adalah Penelitian Tindakan Kelas (PTK) Kolaboratif. Peneliti berkolaborasi dengan guru sebagai pelaksana kegiatan pembelajaran. Subjek penelitian ini adalah siswa kelas IV SD Negeri Padasuka 2 Kecamatan Pasirwangi Kab. Garut. Objek dari penelitian ini adalah kemampuan siswa dalam memecahkan masalah matematika terkait pecahan melalui penerapan Pendidikan Matematika Realistik. Pengumpulan data dalam penelitian ini menggunakan tes dalam bentuk uraian terbatas yang dilakukan tiap akhir siklus, dan observasi yang dilakukan oleh peneliti. Data aktivitas siswa dan guru dalam pembelajaran dianalisis secara deskriptif kualitatif dan data hasil tes kemampuan memecahkan masalah dianalisis secara deskriptif kuantitatif dengan penyajian tabel dan persentase. Hasil penelitian menunjukkan bahwa penerapan Pendidikan Matematika Realistik yang dilaksanakan dengan menggunakan langkah-langkah PMR yang didasarkan pada karakteristik PMR yaitu penggunaan masalah kontekstual, penggunaan model, kontribusi siswa, kegiatan interaktif, dan keterkaitan topik dapat meningkatkan kemampuan memecahkan masalah siswa. Hal tersebut terbukti dengan adanya peningkatan nilai rata-rata hasil evaluasi siswa. Nilai rata-rata sebelum tindakan adalah 62,78 dengan ketuntasan belajar 37,84\%, nilai rata-rata siklus pertama adalah 63,76 dengan ketuntasan belajar sebesar 54,05\%, nilai rata-rata siklus kedua adalah 71,57 dengan ketuntasan belajar sebesar 75,68\%, dan nilai rata-rata siklus ketiga adalah 73,30 dengan ketuntasan belajar sebesar 86,49\%. Maka dapat disimpulkan bahwa penerapan Pendidikan Matematika Realistik (PMR) dapat meningkatkan aktivitas guru dan aktivitas siswa sehingga berdampak pada peningkatan kemampuan siswa dalam memecahkan masalah pecahan penjumlahan dan pengurangan pecahan siswa kelas IV SD Negeri Padasuka 2.
\end{abstract}

Kata Kunci:

Hasil belajar matematika, Pendekatan matematika realistik, kemampuan memecahkan masalah pecahan. 


\section{A. PENDAHULUAN}

Pembelajaran matematika menurut Permen No. 22 Tahun 2006, perlu diberikan kepada semua peserta didik mulai dari tingkat sekolah dasar untuk membekali peserta didik agar memiliki kemampuan berpikir logis, analitis, sistematis, kritis, dan kreatif, serta kemampuan bekerjasama. Kemampuan siswa dalam pemecahan masalah baik masalah matematika maupun masalah lain yang menggunakan matematika merupakan salah satu kemampuan yang harus dikuasai siswa setelah belajar matematika. Kemampuan ini sangat diperlukan siswa terkait dengan kebutuhan siswa untuk memecahkan masalah yang dihadapinya dalam kehidupan sehari-hari dan mampu mengembangkan diri mereka sendiri.Oleh sebab itu, kemampuan pemecahan masalah perlu mendapatkan perhatian khusus dalam proses pembelajaran matematika dari jenjang pendidikan formal paling dasar, yaitu di SD. Menurut National Council of Supervisors of Mathematics (NCSM 1977) ${ }^{1}$ bahwa "learning to solve problems is the principal reason for studying mathematics" dan National Council of Teacher of Mathematics (NCTM 1980) ${ }^{2}$ menjelaskan bahwa problem solving must be the focus of the curriculum.

Kenyataannya, di SD, pembelajaran matematika yang mengembangkan kemampuan pemecahan masalah belum mendapat banyak perhatian dari guru-guru. Terbukti bahwa pelajaran matematika masih menjadi pobia bagi kebanyakan siswa, hasil tes Trends in International Mathematics and Science Study (TIMSS 2003) yang dikoordinir oleh The International for Evaluation of Education Achievement (IEA) tentang kemampuan Matematika dan Sains siswa usia 9-13 tahun menempatkan Indonesia pada peringkat ke-34 penguasaan Matematika dan peringkat ke-36 penguasaan Sains dari 50 negara peserta. Salah satu penyebab rendahnya prestasi matematika siswa adalah dikarenakan belajar matematika siswa belum bermakna (Soviawati 2011), pada prosesnya pembelajaran matematika hanya menekankan pada pencapaian penguasaan materi secara tekstual. Sehingga pemahaman siswa

\footnotetext{
${ }^{1}$ National Council of Supervisors of Mathematics 1977

${ }^{2}$ National Council of Teacher of Mathematics 1980
}

tentang konsep sangat lemah. Hasil survey PISA tahun 2003 juga menunjukkan bahwa kemampuan siswa Indonesia usia 15 tahun pada domain pemecahan masalah masih rendah. Hasil survey ini dapat dijadikan petunjuk bahwa kemampuan matematika siswa pada jenjang sebelumnya, yaitu Sekolah Dasar kurang optimal (The PISA Assessment Framework 2004) ${ }^{3}$

Materi pecahan merupakan salah satu materi yang dipelajari di SD, kontennya mulai dari pengenalan dan pengerjaan operasi hitung dasar. Materi pecahan yang dipelajari siswa kelas IV SD terurai dalam 1 standar kompetensi, yaitu menggunakan pecahan dalam pemecahan masalah dan 5 kompetensi dasar, yaitu menjelaskan arti pecahan dan urutannya, menyederhanakan berbagai bentuk pecahan, menjumlahkan pecahan, mengurangkan pecahan, dan menyelesaikan masalah yang berkaitan dengan pecahan. Dalam membelajarkan materi abstrak seperti pecahan, banyak guru menyampaikan materi tersebut melalui ceramah dan penugasan saja sehingga berdampak pada rendahnya kemampuan pemecahan masalah siswa dalam materi pecahan ${ }^{4}$. Padahal anak usia Sekolah Dasar secara psikologis belum mampu merumuskan semua alternatif jawaban yang mungkin dari sebuah masalah. Jenning dan Dunne (1999) mengatakan bahwa, kebanyakan siswa mengalami kesulitan dalam mengaplikasikan matematika ke dalam situasi kehidupan real ${ }^{5}$. Guru dalam pembelajarannya di kelas tidak mengaitkan dengan skema yang telah dimiliki oleh siswa dan siswa kurang diberikan kesempatan untuk menemukan kembali dan mengkonstruksi sendiri ide-ide matematika. Tipe pembelajaran yang berpusat pada guru ${ }^{8}$ menunjukkan kinerja guru yang jarang memberi konteks untuk menghubungkan materi pelajaran dengan masalah nyata yang sering dihadapi siswa sehingga siswa kurang mampu memecahkan masalah matematika dalam kehidupan sehari-hari ${ }^{9}$.

\footnotetext{
3 Program of International Student Assessment (The PISA Assessment Framework ,2004)

${ }^{4}$ Sukayati "Pembelajaran Operasi Penjumlahan Pecahan di SD Menggunakan Berbagai media 2008" (PPPPTK Matematika, Sleman,2000)

5 Soedjadi "Nuansa Kurikulum Matematika Sekolah di Indonesia" (Konferensi nasional Matematika X ITB, 2000) 17
} 606 | Naturalistic: Jurnal Kajian Penelitan dan Pendidikan dan Pembelajaran Vol.4, No.2b (April 2020): 605-614 
Pembelajaran matematika di SD tentunya harus disesuaikan dengan kebutuhan dan karakteristik siswa SD yang masih berada pada tahap operasional konkrit. Sehingga diperlukan inovasi pembelajaran Matematika yang menyenangkan bagi siswa khususnya siswa SD. Untuk meningkatkan kemampuan pemecahan masalah siswa, perlu didukung oleh metode pembelajaran yang tepat ${ }^{6}$. Salah satu pembelajaran yang tepat sesuai dengan kehidupan riil anak didik agar mampu meningkatkan kemampuan pemecahan masalah adalah melalui pendekatan Pendidikan Matematik Realistik. Pembelajaran matematika berdasarkan pendekatan pendidikan matematika realistik merupakan pembelajaran yang bertitik tolak dari hal-hal yang nyata atau pernah dialami siswa, menekankan keterampilan proses yaitu memberikan kesempatan atau menciptakan peluang sehingga siswa aktif bermatematik ${ }^{7}$.

Siswa yang aktif akan mampu mengembangkan penalaran matematika ${ }^{8}$. Penalaran matematika merupakan pondasi awal seorang siswa memiliki penyelesaian masalah dalam kehidupan sehari-hari. Aktivitas matematika berkaitan dengan pemikiran, sehingga penalaran merupakan bagian penting dalam penyelesaian masalah matematika . Begitu pentingnya penalaran dalam pembelajaran Matematika untuk meningkatkan kemampuan pemecahan masalah matematika, maka pendekatan dalam pembelajaran dan pengajaran Matematika perlu diberikan dengan cara yang menyenangkan sehingga lebih mudah dipahami siswa.

Penelitian ini memiliki tujuan untuk mengidentifikasikan pelaksanaan pembelajaran pendekatan pendidikan matematik realistik tentang pecahan. Pendekatan PMR merupakan salah satu pendekatan pembelajaran yang berawal dari keadaan siswa yang sebenarnya ${ }^{9}$ yang

6 Sumartini., "Peningkatan Kemampuan Pemecahan Masalah Matematis Siswa Melalui Pembelajaran Berbasis Masalah" (Jurnal Pendidikan Matematika Vol 8 No 3 STKIP Garut, 2016)

7 Sabandar ., Aspek Kontekstual Dalam Soal Matematika Dalam Realistics Mathematics Education. ( 2001)

8 Shadiq., "Penalaran Pemecahan Masalah Matematika dan komunikasI Dalam Pembelajaran Matematika (PPPG Matematika, 2004)

9 Lange., "Mathematics Insight And Meaning”(Utrecth, Rijkuniversiteit 1987) mengkaitkan pengalaman kehidupan nyata anak dengan ide-ide matematika ${ }^{10}$ sehingga pembelajaran menjadi lebih bermakna ${ }^{11}$. Pendekatan ini menjanjikan berpeluang besar terhadap peningkatan hasil belajar Matematika siswa sehingga diharapkan dapat meningkatkan kemampuan siswa dalam penyelesaian masalah ${ }^{12}$.

Metode yang digunakan dalam penelitian ini adalah Penelitian Tindakan Kelas yang bersifat kolaboratif. Salah satu ciri khas PTK adalah adanya kolaborasi atau kerjasama antara praktisi dan peneliti dalam pemahaman, kesepakatan tentang permasalahan, pengambilan keputusan yang akhirnya melahirkan tindakan (action) ${ }^{13}$. Subjek penelitian ini adalah siswa kelas IV SDN Padasuka 2 Kec. Pasirwangi Kab. Garut.

\section{B. HASIL DAN PEMBAHASAN}

\section{Hasil Penelitian}

Hasil penelitian tindakan kelas yang telah dilaksanakan meliputi hasil tes kemampuan memecahkan masalah matematika siklus I hasil tes kemampuan memecahkan masalah matematik siklus II dan tes kemampuan memecahkan masalah matematika siklus III, serta hasil observasi aktivitas guru dan siswa dalam penerapan pendidikan matematika realistik (PMR). Adapun hasilnya tes sebagai berikut :

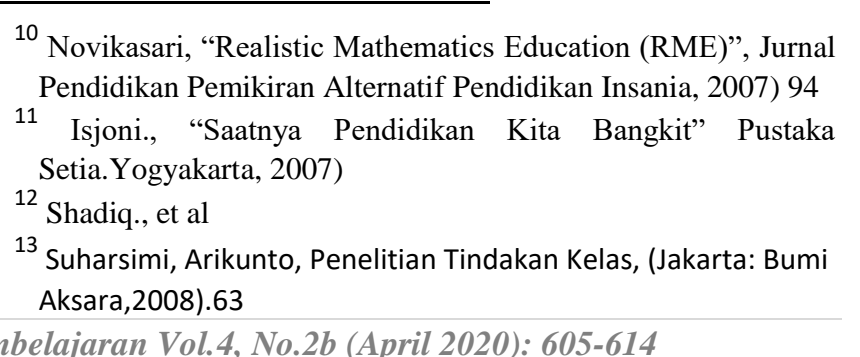


Tabel 1.

Hasil Tes Kemampuan Matematika

\begin{tabular}{|c|c|c|c|c|c|c|c|}
\hline \multirow{2}{*}{$\begin{array}{c}\text { Nomor } \\
\text { Item }\end{array}$} & \multirow{2}{*}{$\begin{array}{c}\text { Skor } \\
\text { Maks }\end{array}$} & \multicolumn{2}{|c|}{ Siklus I } & \multicolumn{2}{c|}{ Siklus II } & \multicolumn{2}{c|}{ Siklus III } \\
\cline { 3 - 8 } & Pert 1 & Pert 1 & Pert 1 & Pert 2 & Pert 2 & Pert 2 \\
\hline 1 & 4 & 2 & 3 & 3 & 4 & 3 & 3 \\
\hline 2 & 4 & 2 & 3 & 3 & 4 & 3 & 3 \\
\hline 3 & 4 & 2 & 2 & 3 & 3 & 4 & 4 \\
\hline 4 & 4 & 2 & 3 & 3 & 3 & 4 & 4 \\
\hline 5 & 4 & 2 & 2 & 2 & 3 & 3 & 3 \\
\hline 6 & 4 & 2 & 2 & 2 & 3 & 3 & 3 \\
\hline 7 & 4 & 3 & 3 & 3 & 3 & 3 & 3 \\
\hline 8 & 4 & 2 & 3 & 3 & 3 & 3 & 3 \\
\hline 9 & 4 & 2 & 3 & 3 & 3 & 3 & 4 \\
\hline 10 & 4 & 3 & 3 & 3 & 4 & 3 & 3 \\
\hline 11 & 4 & 3 & 3 & 3 & 3 & 3 & 3 \\
\hline 12 & 4 & 2 & 3 & 3 & 3 & 3 & 3 \\
\hline 13 & 4 & 2 & 2 & 3 & 3 & 4 & 4 \\
\hline $\begin{array}{c}\text { Jumlah } \\
\text { Skore }\end{array}$ & 52 & 29 & 35 & 37 & 42 & 42 & 43 \\
\hline $\begin{array}{c}\text { Persentas } \\
\text { e }\end{array}$ & & $56 \%$ & $67 \%$ & $71 \%$ & $81 \%$ & $81 \%$ & $83 \%$ \\
\hline \begin{tabular}{c} 
Kriteria \\
\hline
\end{tabular} & & $\begin{array}{c}\text { Sangat } \\
\text { Rendah }\end{array}$ & Rendah & Sedang & Tinggi & Tinggi & Tinggi \\
\hline
\end{tabular}

Deskripsi hasil penelitian ini adalah hasil observasi , observasi dilakukan setiap pertemuan. Data hasil observasi digunakan untuk mengetahui penerapan Pendidikan Matematika Realistik oleh guru dan respon siswa dalam penerapan pendidikan Matematika Realistik. Berikut ini adalah hasil observasi:

a. Hasil Observasi Aktivitas Guru dalam penerapan Pendidikan Matematika Realistik.
Observasi terhadap penerapan Pendidikan Matematika Realistik (PMR) oleh guru menggunakan lembar observasi yang terdiri dari 13 butir dengan menggunakan skala Likert dengan 4 pilihan jawaban. Berikut ini adalah hasil observasi dari masing-masing siklus. Observasi aktivitas guru dalam penerapan PMR tiap siklus dapat dilihat dalam diagram berikut:

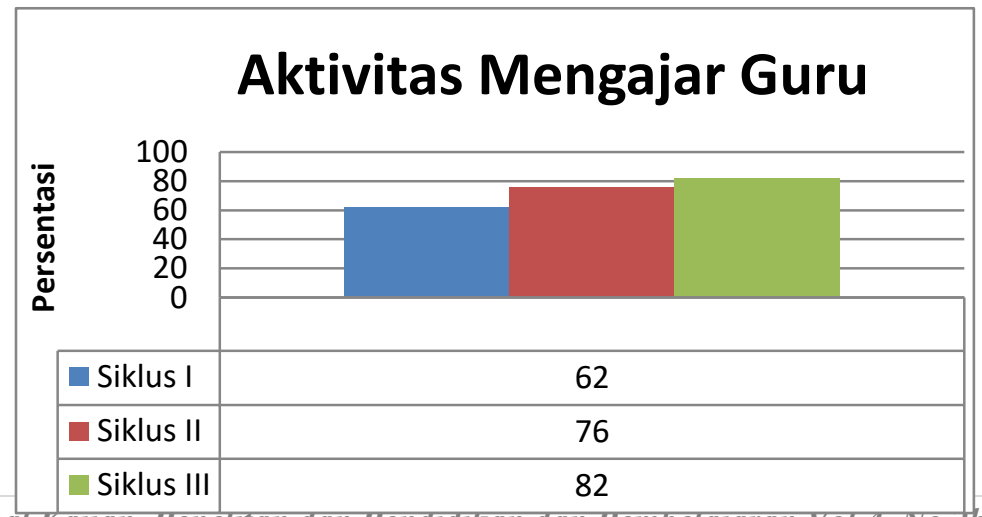


Gambar 1.

Hasil Observai Aktivitas Guru dalam Penerapan PMR

\section{b. Aktivitas Siswa dalam Penerapan PMR}

Observasi terhadap aktivitas siswa dalam penerapan Pendidikan Matematika Realistik (PMR) menggunakan lembar observasi yang terdiri dari 13 butir dengan menggunakan skala Likert dengan 4 pilihan jawaban. Berikut ini adalah hasil observasi dari masing-masing siklus.

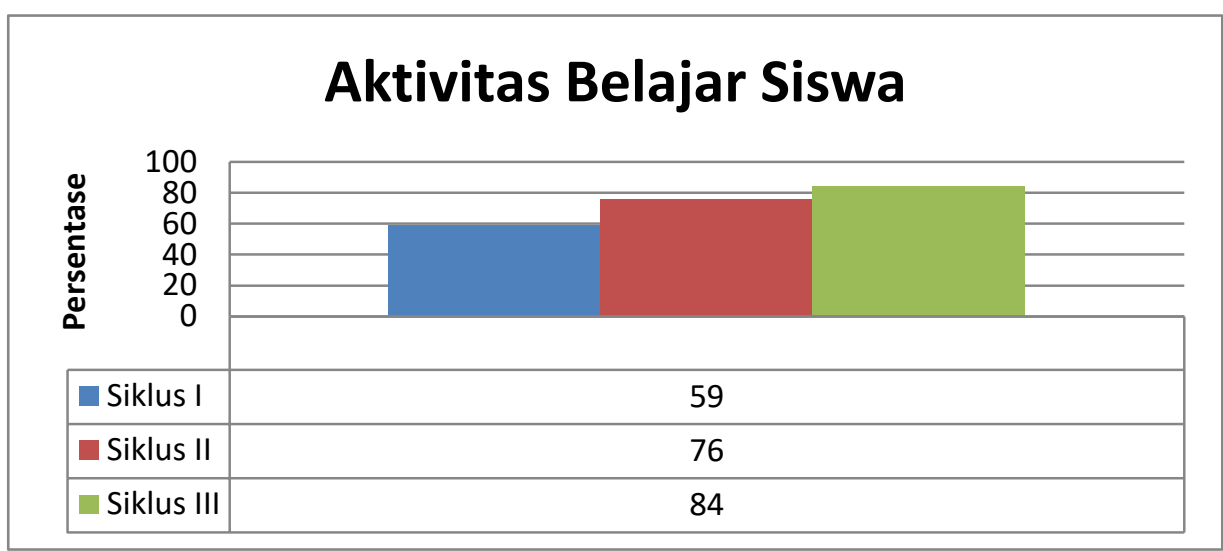

Gambar 2.

Hasil Observasi Aktivitas Belajar Siswa dalam Penerapan PMR

c. Hasil Tes Kemampuan Memecahkan Masalah Matematika

Hasil tes kemampuan awal, tes siklus I, tes siklus II, dan tes siklus III digunakan sebagai tolak ukur ada tidaknya peningkatan kemampuan siswa kelas IV SD Negeri Padasuka 2 dalam memecahkan masalah matematika. Berdasarkan hasil tes yang diperoleh menunjukkan bahwa kemampuan siswa dalam memecahkan masalah matematika khususnya pecahan pada siswa kelas IV SDN Padasuka 2 mengalami peningkatan setelah diterapkannya PMR. Berikut ini adalah hasil tes kemampuan memecahkan masalah matematika.

Tabel 2. Hasil Tes Kemampuan Memecahkan Masalah Matematika

\begin{tabular}{|c|c|c|c|c|}
\hline & $\begin{array}{c}\text { Tes } \\
\text { Kemampuan } \\
\text { Pra Siklus }\end{array}$ & $\begin{array}{c}\text { Tes } \\
\text { Kemampuan } \\
\text { Siklus 1 }\end{array}$ & $\begin{array}{c}\text { Tes } \\
\text { Kemampuan } \\
\text { Siklus II }\end{array}$ & $\begin{array}{c}\text { Tes } \\
\text { Kemampuan } \\
\text { Siklus III }\end{array}$ \\
\hline $\begin{array}{c}\text { Nilai Rata-rata } \\
\text { Siswa }\end{array}$ & 62,78 & 63,76 & 71,57 & 73,30 \\
\hline Siswa yang tuntas & 14 & 20 & 28 & 32 \\
\hline $\begin{array}{c}\text { Siswa yang belum } \\
\text { Tuntas }\end{array}$ & 23 & 17 & 9 & 5 \\
\hline $\begin{array}{c}\text { Persentase } \\
\text { ketuntasan }\end{array}$ & $38,84 \%$ & $54,05 \%$ & $75,68 \%$ & $86,49 \%$ \\
\hline Kualifikasi & Sangat Rendah & Sangat Rendah & Sedang & Tinggi \\
\hline
\end{tabular}


Berikut ini adalah diagram ketuntasan belajar siswa mulai dari sebelum dilakukan tindakan, siklus I, siklus II, dan siklus III:

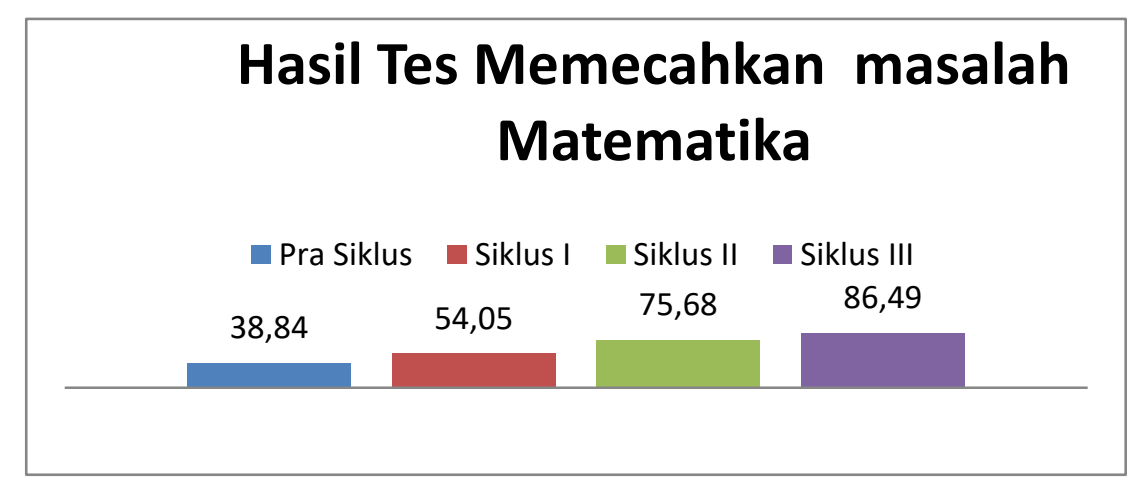

Gambar 3. Diagram Persentase Ketuntasan Belajar Tiap Siswa

Dari tabel di atas dapat dilihat bahwa ketuntasan belajar sebelum dilakukan tindakan $38,84 \%$, setelah dilakukan tindakan pada siklus I ketuntasan belajar menjadi 54,05\%, ketuntasan belajar pada siklus II menjadi $75,68 \%$, dan ketuntasan belajar pada siklus III menjadi $86,49 \%$.

\section{d. Hasil Observasi Ranah Afektif Siswa}

Hasil observasi ranah afektif siswa digunakan sebagai alat ukur sebagai proses penerimaan dan penerapan nilai-nilai selama proses mendapatkan pengalaman belajar yang mempengaruhi pola kepribadian dan tingkah laku selama proses pembelajaran berlangsung. Penerimaan, jawaban atau reaksi, penilaian, organisasi dan internalisasi adalah bentuk dari ranah efektif peserta yang berdasarkan hasil observasi peneliti menunjukan bahwa aspek afektif siswa dalam pelaksanaan pembelajaran maupun selama penerapan pembelajaran di internalisasi dalam kehidupan sehari-hari khususnya siswa kelas IV SDN Padasuka 2, karena sikap berhubungan dengan dengan nilainilai yang ingin ditanamkan dalam diri peserta didik.

Tabel 3. Observasi Ranah Afektif Siswa

\begin{tabular}{|c|c|c|c|c|c|c|}
\hline & \multicolumn{2}{|c|}{ Siklus I } & \multicolumn{2}{|c|}{ Siklus II } & \multicolumn{2}{|c|}{ Siklus III } \\
\hline & Pert 1 & Pert 2 & Pert 1 & Pert 2 & Pert 1 & Pert 2 \\
\hline Nilai Rata-rata Siswa & 6,36 & 7,22 & 9,01 & 9,14 & 9,27 & 9,61 \\
\hline Kriteria Persentase & Cukup & Cukup & Baik & Baik & Baik & Baik \\
\hline $\begin{array}{c}\text { Rata-rata hasil } \\
\text { Observasi }\end{array}$ & \multicolumn{2}{|c|}{6,79} & \multicolumn{2}{|c|}{9,07} & \multicolumn{2}{|c|}{9,44} \\
\hline Kualifikasi & \multicolumn{2}{|c|}{ Kurang Baik } & \multicolumn{2}{|c|}{ Baik } & \multicolumn{2}{|c|}{ Baik } \\
\hline
\end{tabular}

Berdasarkan ıеmıdir uoservası akıvılas guru dalam penerapan PMR dapat dilihat bahwa aktivitas guru mengalami peningkatan mulai siklus I pertemuan 1 ke siklus III pertemuan 2 . Pada siklus I pertemuan 1 aktivitas guru dalam penerapan PMR dalam kategori cukup baik dengan persentase keterlaksanaan sebesar 56\%,

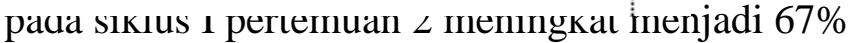
dalam kategori sedang. Angka ini belum memenuhi kriteria yang ingin dicapai, oleh karena itu penerapan PMR pada siklus I ini di refleksi untuk kemudian diadakan perbaikan kegiatan pembelajaran pada siklus II. Pada siklus II pertemuan 1, persentase aktivitas guru dalam 
penerapan PMR sebesar $71 \%$ dalam kategori sedang, angka ini meningkat pada siklus II pertemuan 2 menjadi $81 \%$ dalam kategori sangat tinggi. Sehubungan dengan perencanaan pada pelaksanaan siklus menjadi tiga siklus maka peneliti melaksanakan penerapan PMR pada siklus II direfleksikan untuk kemudian diadakan kegiatan pembelajaran siklus III. Pada siklus III pertemuan 1, persentasi aktivitas guru dalam penerapan PMR sebesar $81 \%$ dalam kategori tinggi, angka ini meningkat pada siklus III pertemuan 2 menjadi 83\% dalam kategori tinggi.

Peningkatan aktivitas guru dalam penerapan PMR ini berbanding lurus dengan aktivitas siswa dalam pembelajaran. Aktivitas siswa selama pembelajaran berlangsung juga mengalami peningkatan. Berdasarkan lembar observasi aktivitas siswa dalam penerapan PMR dapat dilihat bahwa aktivitas siswa mengalami peningkatan mulai siklus I pertemuan 1 ke siklus III pertemuan 2. Pada siklus I pertemuan 1 aktivitas siswa dalam penerapan PMR dalam kategori cukup baik dengan persentase keterlaksanaan sebesar $56 \%$, pada siklus I pertemuan 2 meningkat menjadi $62 \%$ dalam kategori rendah. Angka ini belum memenuhi kriteria yang ingin dicapai, oleh karena itu penerapan PMR pada siklus I ini di refleksi untuk kemudian diadakan perbaikan untuk pembelajaran pada siklus II. Pada siklus II pertemuan 1, persentase aktivitas siswa dalam penerapan PMR sebesar 69\% dalam kategori sedang, angka ini meningkat pada siklus II pertemuan 2 menjadi $83 \%$ dalam kategori tinggi. Penerapan PMR pada siklus II ini di refleksi untuk kemudian diadakan perbaikan untuk pembelajaran pada siklus III Pada siklus III pertemuan 1, persentase aktivitas siswa dalam penerapan PMR sebesar $83 \%$ dalam kategori tinggi, angka ini meningkat pada siklus III pertemuan 2 menjadi $85 \%$ dalam kategori tinggi.

Aktivitas guru dan siswa sama-sama meningkat dari siklus I ke siklus III. Hal ini berdampak pada meningkat pula kemampuan siswa dalam memecahkan masalah penjumlahan dan pengurangan pecahan.

Hasil tes yang dilakukan setelah dilaksanakannya tindakan menerapkan Pendekatan Matematika Realistik (PMR) terus mengalami peningkatan dan menunjukkan keefektifan PMR. Hasil penelitian menunjukkan nilai rata-rata tes kemampuan memecahkan masalah mengalami peningkatan dari sebelum dilakukannya tindakan sampai setelah dilakukan tindakan. Nilai rata-rata pada saat pra tindakan sebesar 62,78 dengan ketuntasan belajar sebesar $37,84 \%$. Pada siklus I nilai rata-rata meningkat menjadi 63,76 dengan ketuntasan belajar 54,05\% . Meskipun nilai rata-rata ini meningkat tapi belum mencapai kriteria yang ingin dicapai sehingga dilanjutkan ke siklus II. Pada siklus II nilai ratarata meningkat menjadi 71,57 dengan ketuntasan belajar sebesar $75,68 \%$. Pada siklus II, ketuntasan sebesar 75,68\%. Masih belum mencapai kriteria keberhasilan tindakan yang ingin dicapai, sehingga tindakan dilanjutkan sampai siklus III. Pada siklus III nilai rata-rata meningkat menjadi 73,30 dengan ketuntasan belajar sebesar 86,49\%. Pada siklus III, ketuntasan sebesar 86,49\%. sudah mencapai kriteria keberhasilan tindakan yang ingin dicapai, sehingga tindakan dihentikan sampai siklus III.

\section{PEMBAHASAN}

Pelaksanaan pembelajaran matematika materi pecahan dengan menggunakan pendekatan Pendidikan Matematika Realistik di sekolah dasar yang berorientasi pada karakteristik-karakteristik Realistic Mathematics Education (RME), memberikan kesempatan kepada siswa dalam menemukan kembali konsep-konsep matematika atau pengetahuan matematika formal14. Pada prosesnya, siswa diberi kesempatan mengaplikasikan konsep-konsep matematika untuk memecahkan masalah sehari-hari atau masalah dalam bidang lain. Pembelajaran realistik merupakan salah satu strategi yang bisa mengembangkan kecerdasan majemuk siswa15. Artinya, tidak hanya aktivitas belajar saja yang berkembang, tetapi aspek afektif menjadi pertimbangan dalam penilaian kemampuan belajar siswa. Dilihat dari hasil penelitian PTK ini, menunjukkan bahwa penerapan Pendidikan

14 Soviawati., "Pendekatan Matematika Realistik Untuk Meningkatkan Kemampuan Berpikir Siswa di Tingkat Sekolah Dasar" (Edisi Khusus ; ISSN 1412-565X,2011)

15 N. M. Sanusi n.d., "Pembelajaran Matematika Realistik Dapat mengoptimalkan Kecerdasan majemuk Siswa" t.tahun. hal 150 
Matematika Realistik yang dilaksanakan dengan menggunakan langkah-langkah PMR didasarkan pada karakteristik PMR meliputi penggunaan masalah kontekstual, penggunaan model, kontribusi siswa, kegiatan interaktif, dan keterkaitan topik dapat meningkatkan kemampuan memecahkan masalah siswa sehingga bisa pula meningkatkan kemampuan pemecahan bahkan penalaran Matematik siswa secara signifikan16.

Hal tersebut terbukti dengan adanya peningkatan nilai rata-rata hasil evaluasi siswa. Nilai rata-rata sebelum tindakan adalah 62,78 dengan ketuntasan belajar $37,84 \%$, nilai rata-rata siklus pertama adalah 63,76 dengan ketuntasan belajar sebesar $54,05 \%$, nilai rata-rata siklus kedua adalah 71,57 dengan ketuntasan belajar sebesar $75,68 \%$, dan nilai rata-rata siklus ketiga adalah 73,30 dengan ketuntasan belajar sebesar $86,49 \%$.

Secara teoritis keterlaksanaan perencanaan pembelajaran matematika materi pecahan dengan menggunakan pendekatan Pendidikan Realistic Matematik memberikan gambaran bahwa pendekatan ini sangat efektif digunakan mengingat pada prosesnya siswa diarahkan untuk mengkonstruk sendiri materi yang dipelajari ketika berdiskusi dengan teman sebaya. PMR ini memiliki karakteristik pembelajaran berbasis konstruktivis, Menurut Vygotsky (Taylor, 1993) ketika siswa mengkonstruksi suatu konsep, mereka perlu memperhatikan lingkungan sosial (Konstruktivisme Sosial). Dalam mengkonstruk pemikiran, ada konsep Scaffolding yaitu suatu bentuk bantuan yang diberikan kepada siswa untuk belajar dan memecahkan masalah. Bantuan tersebut dapat berupa petunjuk, dorongan, peringatan, menguraikan masalah ke dalam langkah-langkah pemecahan, memberikan contoh, dan tindakan-tindakan lain yang memungkinkan siswa itu belajar mandiri.

Aktivitas siswa ketika berinteraksi dengan guru dan siswa lainnya didasarkan pada pengalaman informal siswa dalam mengembangkan strategi-strategi untuk merespon masalah yang diberikan. Karakteristik pendekatan konstruktivis sosial ini sesuai dengan karakteristik

16 Herawati., Efektivitas Pendekatan Realistik Dalam Meningkatkan Kemampuan Penalaran Matematika..." (Jurnal Peluang, 2015) hal 12
RME. Konsep ZPD dan Scaffolding dalam pendekatan konstruktivis sosial di dalam pembelajaran matematika realistik disebut dengan penemuan kembali terbimbing (guided reinvention $)^{17}$.

Aktivitas belajar siswa dalam hal kemampuan pemecahan masalah mengalami peningkatan menurut Marpaung (2005) hal itu terjadi disebabkan oleh beberapa aktivitas yang sangat strategis diantaranya; (1) Siswa aktif, guru aktif. Siswa aktif mengkonstruksi materi yang dipelajari, sedangkan guru aktif mengarahkan siswa dalam mengkonstruksi materi yang dipelajarinya. (2) Pembelajaran diusahakan dimulai dari keadaan yang nyata atau real. (3) Guru memberikan kesempatan kepada siswa untuk menyelesaikan masalah dengan cara sendiri. (4) Guru menciptakan suasana pembelajaran yang menyenangkan, sehingga suasana di dalam kelas tidak tegang. (5) Siswa dapat menyelesaikan masalah dalam kelompok atau secara individual. (6) Pembelajaran tidak selalu di kelas. (7) Guru mendorong terjadinya interaksi dan negosiasi, baik antara guru dan siswa, maupun antara siswa dengan siswa. (8) Siswa bebas memilih representasi yang sesuai dengan struktur kognitifnya sewaktu menyelesaikan masalah. (9) Guru bertindak sebagai fasilitator. Guru menghargai pendapat siswa, termasuk pendapat itu betul atau salah karena pada prosesnya guru menggunakan pendekatan yang santun, terbuka dan komunikatif selama proses pembelajaran ${ }^{18}$.

Peningkatan kemampuan pemecahan masalah pada siswa akan berhasil jika siswa aktif mengkonstruksi sendiri materi yang dipelajarinya. Peran guru hanya membantu menyediakan sarana dan prasarana agar proses konstruksi siswa berjalan dengan baik. Marpaung menambahkan bahwa kecerdasan matematis-logis akan terpenuhi dalam pembelajaran Pendidikan Matematik Realistik jika siswa memiliki kemampuan matematis yang baik dan penalaran

17 Mustamin., Pembelajaran Matematika Dengan Pendekatan Realistik" (Jurnal Lentera Pendidikan, 2017)

18 Marpaung., "Dampak Pembelajaran Pada Proses Berpikir Siswa di SD Melalui PMRI dan Non PMRI," 2005) 
yang kuat, sehingga dalam pembelajarannya akan lebih optimal ${ }^{19}$.

Beberapa penelitian terdahulu di beberapa negara menurut Kuiper \& Knuver $(1993)^{20}$ menunjukkan bahwa pembelajaran menggunakan pendekatan realistic membuktikan bahwa pelajaran (1) Matematika lebih menarik, relevan, dan bermakna, tidak terlalu formal dan tidak terlalu abstrak, (2) Mempertimbangkan tingkat kemampuan siswa, (3) Menekankan belajar matematika pada "Learning by doing"e. (4) Memfasilitasi penyelesaian masalah matematika tanpa menggunakan penyelesaian (algoritma) yang baku. Dan (5) Menggunakan konteks sebagai titik awal pembelajaran matematika. Hal itu membuktikan bahwa pendekatan Pendidikan Matematik Realistik mampu meningkatkan kemampuan pemecahan masalah siswa di Sekolah Dasar. Terbukti dari hasil Penelitian Tindakan Kelas ini menunjukkan peningkatan yang signifikan dalam aspek kemampuan pemecahan masalah matematis siswa.

\section{SIMPULAN}

Berdasarkan hasil penelitian dan pembahasan maka dapat disimpulkan bahwa penerapan Pendidikan Matematika Realistik (PMR) dapat meningkatkan aktivitas guru dan aktivitas siswa sehingga berdampak pada peningkatan kemampuan siswa dalam memecahkan masalah pecahan penjumlahan dan pengurangan pecahan siswa kelas IV SD Negeri Padasuka 2.

\section{Keterlaksanaan Perencanaan Penerapan Pendekatan Matematika Realistik.}

Pada tahap perencanaan, peneliti merencanakan kegiatan yang dilakukan pada Penelitian Tindakan Kelas (PTK), adapun kegiatan yang dilakukan dalam perencanaan adalah sebagai berikut :

\footnotetext{
19 N. M. Sanusi n.d., et.al Pembelajaran Realistik Matematik...hal 160

20 Mustamin, et.al., "Pembelajaran Matematika Dengan

Pendekatan Matematik Realistik" hal 234
}

613 | Naturalistic: Jurnal Kajian Penelitan dan Pendidikan dan Pembelajaran Vol.4, No.2b (April 2020): 605-614 a. Membuat skenario pelaksanaan tindakan atau rencana pelaksanaan pembelajaran (RPP) yang disesuaikan dengan karakteristik PMR.

b. Membuat lembar observasi: untuk melihat bagaimana aktivitas belajar siswa dan aktivitas mengajar guru di kelas ketika PMR dilaksanakan pada mata pelajaran matematika.

c. Membuat media pembelajaran yang diperlukan dalam rangka membantu siswa memahami konsep-konsep matematika dengan baik.

d. Mendesain alat evaluasi untuk melihat apakah materi yang disampaikan telah dikuasai oleh siswa.

\section{Keterlaksanaan Penerapan Pendekatan Matematika Realistik}

Hasil penelitian menunjukkan keterlaksanaan penerapan PMR pada siklus I berdasarkan lembar observasi aktivitas guru sebesar $62 \%$ dan pada siklus III sebesar $82 \%$. Sedangkan berdasarkan lembar aktivitas siswa pada siklus I sebesar 59\% dan pada siklus III sebesar $84 \%$. Ini menunjukkan bahwa aktivitas guru dan aktivitas siswa setelah diterapkan PMR pada siklus III mengalami peningkatan dibandingkan siklus I.

\section{Peningkatan Aktivitas dan Hasil Pembelajaran Memecahkan Masalah \\ Peningkatan aktivitas guru dan aktivitas} siswa dalam penerapan PMR berdampak pada peningkatan hasil tes kemampuan memecahkan masalah siswa. Hasil tes kemampuan menunjukkan bahwa pada siklus I nilai rata-rata siswa adalah 63,76 dengan persentase ketuntasan sebesar 54,05\%, sedangkan pada siklus III nilai rata-rata siswa adalah 73,30 dengan persentase ketuntasan sebesar $86,49 \%$. Ini menunjukkan bahwa kemampuan siswa mengalami peningkatan.

Hasil observasi menunjukkan keterlaksanaan penerapan PMR pada pada pelaksanaan pembelajaran mengalami 
peningkatan tingkah laku untuk berbuat sesuatu, melaksanakan, dan menerima, yang mengacu pada proses pembelajaran. Peneliti dalam mengukur sikap memperhatikan pada 3 komponen sikap. Yang menunjukan hasil perubahan perilaku belajar siswa yang baik dan terarah sesuai tahap perkembangan peserta didik.

Dengan demikian, ini membuktikan bahwa penerapan Pendidikan Matematika Realistik dapat meningkatkan aktivitas guru dan aktivitas siswa sehingga berdampak pula pada peningkatan kemampuan siswa dalam memecahkan masalah penjumlahan dan pengurangan pecahan.

\section{DAFTAR PUSTAKA}

\section{Buku}

Arikunto, Suharsimi. Penelitian Tindakan Kelas. Jakarta: Bumi Aksara. 2008.

Isjoni. Saatnya Pendidikan Kita Bangkit. Yogyakarta: Pustaka Siswa, 2007.

Lange, De. Mathematics Insight and Meaning. Utrecth: Rijkuniversiteit, 1987.

Marpaung. Dampak Pembelajaran Pada Proses Berfikir Siswa di SD Melalui PMRI dan non PMRI. 2005.

Sukayati. Pembelajaran Operasi Penjumlahan Pecahan di SD Menggunakan Berbagai Media. Sleman: PPPPTK Matematika Depdikbud, 2008.

\section{Jurnal}

Herawati. A. "Efektivitas Pendekatan Realistik Dalam Meningkatkan Kemampuan Penalaran Matematika Di SMA Negeri 1 Tembilahan Inhil Riau" Jurnal Peluang, Volume 4, Nomor 1, Oktober 2015, ISSN: 2302-5158

Mustamin, Siti Hasmiah. "Pembelajaran Matematika Dengan Pendekatan Realistik." Jurnal Lentera Pendidikan Vol.20 No 2 Desember, 2017: 231-239.

Novikasari, Ivada. "Realistic Mathematics Education (RME); Pendekatan Pendidikan Matematik Realistik Dalam Konsep dan Realitas." Jurnal Pendidikan Pemikiran
Alternatif Pendidikan Insania Vol 12 No 1, 2007: 93-106.

Sabandar, I. Aspek Kontekstual Dalam Soal Matematika Dalam Realistic Mathematics Education. Makalah Seminar. UPI Bandung: Tidak Dipublikasikan, 2001.

Sanusi, Neli Ma'rifat. "Pembelajaran Matematika Realistik Dapat Mengoptimalkan Kecerdasan Majemuk." Jurnal Euclid Vol 2 No 1 ISSN 2355-1712, t.thn.: 137-250.

Soviawati, Evi. "Pendekatan Matematika Realistik Untuk Meningkatkan Kemampuan Berfikir Siswa Di Tingkat Sekolah Dasar." Edisi Khusus 2 Agustus, 2011: 79-85 ISSN 1412-565X.

Sumartini, T.S. "Peningkatan Kemampuan Pemecahan Masalah Matematis Siswa Melalui Pembelajaran Berbasis Masalah." Jurnal Pendidikan Matematika Vol 8 No 3 STKIP Garut, 2016.

\section{Prosiding}

Soedjadi. "Nuansa Kurikulum Matematika Sekolah di Indonesia." Konferensi Nasional Matematika X ITB 17-20 Juli 2000. Bandung: Prosiding Majalah Ilmiah

Paper Himpunan Matematika Indonesia, 2000.

Shadiq, Fajar. Penalaran Pemecahan Masalah Matematika dan Komunikasi Dalam Pembelajaran Matematika. Paper, Yogyakarta: PPPG Matematika, 2004.

\section{Report}

Programme of International Student Assessment (PISA). The PISA Assessment Framework. OECD, 2004.

NCSM. "National Council of Supervisors of Mathematics." 1977.

NCTM. "National Council of Teacher of Mathematics." 1980.

TIMSS. The International for Evaluation of Education Achievement (IEA), 2003. 